\title{
ZDRAVSTVENI GLASNIK U PODIZANJU RAZINE ZNANOSTI FAKULTETA ZDRAVSTVENIH STUDIJA SVEUC̆ILIŠTA U MOSTARU
}

Ivan Vasilj, Dragan Babić, Marko Martinac, Josip Šimić, Marko Pavlović, Darjan Franjić

Fakultet zdravstvenih studija Sveučilišta u Mostaru,

88000 Mostar, Bosna i Hercegovina

Rad je primljen 12.04.2021. Rad je recenziran 17.04.2021. Rad je prihvaćen 19.04.2021.

Znanost nije i nikada neće biti gotova knjiga. Svaki važan uspjeh donosi nova pitanja.

Svaki razvoj otkriva vremenom sve veće i dublje poteškoće.

A. Einstein 


\section{UVOD}

U poslijeratnoj Hercegovini zdravstvene službe su bile značajno devastirane i postojala je velika potreba za oporavak i napredak medicine i zdravstva (1). U Mostaru je 2000. g. osnovana Visoka zdravstvena škola, a od 2005. g. studenti na svim studijima upisuju se na preddiplomske sveučilišne studije po novom nastavnom planu i programu koji je prilagođen Bolonjskom procesu. Visoka zdravstvena škola 2008. g. prerasta u Fakultet zdravstvenih studija (FZS). Nova zgrada FZS-a sa suvremenim prostorom i opremom na Bijelom Brijegu završena je 2009. g. (2). Od 2017. g. uz već postojeći preddiplomski i diplomski studij na FZS pokrenut je i doktorski poslijediplomski studij. Zahvaljujući FZS-a razina zaštite zdravlja i borba protiv različitih bolesti u Mostaru i Hercegovini je značajno podignuta (3-5).

U sklopu Sveučilišta u Mostaru proteklih dvadeset i jednu godinu FZS je pokazivao stalni rast $\mathrm{i}$ napredak zahvaljujući ponajviše vrlo sposobnim i vrijednim dekanima, profesorima: Ljubi Šimiću, Mladenu Mimici i Ivanu Vasilju kao i svima drugima koji su vezani za fakultet uključujući i studente. FZS Sveučilišta u Mostaru po mnogim procjenama spada u red najboljih u Bosni i Hercegovini (BiH) i $\mathrm{u}$ regiji. Fakultet se cijelo vrijeme, sukladno svojoj strategiji, bavio i znanstveno-istraživačkim radom, te su naši nastavnici i studenti do sada sudjelovali u više znanstvenih međunarodnih istraživačkih projekata. Proteklih godina organizirano je više različitih simpozija koje su organizirali nastavnici i studenti. Važno je istaknuti da su naši nastavnici, asistenti i studenti na svim tim simpozijima imali važnu aktivnu ulogu koja je nerijetko bila i vodeća jer su vrlo uspješno prezentirali svoje znanstvene i stručne radove. Također su proteklih godina imali aktivno sudjelovanje na regionalnim, europskim i svjetskim kongresima te publicirali brojne radove $\mathrm{u}$ visoko indeksiranim časopisima (6).

Znanošću se trebaju baviti svi studenti, a napose studenti biomedicinskih i sestrinskih ili zdravstvenih fakulteta. A kada se završi fakultet zdravstvenih studija, ta potreba je naprosto prirodna. I nije privilegija samo ambicioznih i onih koji žele "sutra" biti nastavnici na fakultetu koji su završili, nego obveza svih, pa i onih koji žele biti "samo uspješni praktičari i profesionalci”. U želji za što većim opsegom znanja i mogućnosti pružanja što kvalitetnije zdravstvene zaštite, a u cilju edukacije studenata i nastavnog osoblja, znanost na FZS je neupitna potreba i obveza (7). Iznimno je važno imati i vlastite ideje istraživati, povezivati se $s$ realnim sektorom baš onako kako to čini FZS Sveučilišta u Mostaru. Oni znanstvenici koji pronađu srednjih put između ta dva pristupa bit će u prednosti u raznim vrstama vrjednovanja. I zaista život znanstvenika u 21. stoljeću u mnogome se promijenio u odnosu na znanstvenike 20. stoljeća(8).

\section{ZDRAVSTVENI GLASNIK}

Elektronički časopis FZS Sveučilišta u Mostaru, pod imenom Zdravstveni glasnik, objavljujemo s ciljem i nadom da će urođena i prema struci okrenuta radoznalost naših studenata biti iznova potaknuta na znanstveno razmišljanje i znanstveno-istraživački rad, u oblasti koju su izabrali za svoj životni poziv. Ujedno, časopis daje prostor koji će nastavnici i suradnici koristiti za objavljivanje svojih znanstvenih i znanstveno-istraživačkih radova, istovremeno, hrabreći naše studente. Znanstveni časopis je definiran kao periodično izdanje znanstvenih publikacija čija je svrha pratiti aktualna znanstveno-istraživačka dostignuća i unaprijediti znanost. Većinom je specijaliziran za određeno područje znanosti, u našem slučaju zdravstvo i medicinu (9).

Ideja za pokretanje časopisa rodila se 2014. g. da bi nakon detaljne pripreme prvi broj izašao u svibnju 2015. g. Časopis izlazi dva puta godišnje i u proteklih sedam godina uključujući i ovaj izašlo je trinaest brojeva Zdravstvenog glasnika. Objavili smo preko 130 radova u kojima je sudjelovalo preko 300 autora i koautora iz sedam zemalja (Bosna i Hercegovina, Republika Hrvatska, Slovenija, Crna Gora, Kosovo, Italija i Kazahstan). Najveći broj autora i koautora je s našeg fakulteta i s našeg Sveučilišta i iz naše Sveučilišne kliničke bolnice Mostar. Aktivno sudjelovanje uzeli su i autori s drugih sveučilišta $\mathrm{u}$ BiH (Sarajevo, Tuzla, Banja Luka... ).

Naš časopis je indeksiran u četiri akademske baze podataka (Cobbis, Google Scholar, Hrčak i EBSCO), a naš je cilj podizati njegovu razinu na što veću razinu prema citatnim bazama Scopus i WoS. I to je naš 
trajni cilj. Najveći dio objavljenih radova su izvorni znanstveni radovi, ali i pregledni, stručni, prikazi slučaja, eseji, prikazi knjiga.

Do sada objavljeni radovi osim iz drugih centara i država najviše dolaze s većine fakulteta našeg sveučilišta i praktično sa svih klinika. Prema tematologiji kojom se bave do sada publicirani radovi mogu se podijeliti na epidemiološke $(10,11)$, infektološke (12-14), javno zdravstvene koje se odnose na cijepljenje (15-19), druge javnozdravstvene teme (20$23)$, iz područja sestrinstva $(24,25)$, iz područja ginekologije i porodništva (26-28), iz područja onkologije (29-32), kirurgije (33), pedijatrije $(34,35)$, laboratorijske biomedicine (36), fizikalne medicine i rehabilitacije (37-47), iz područja radiologije (4854), hematologije i transfuziologije (55), kardiologije (56), neurologije (57), dijetetike (58), temeljnih medicinskih znanosti - povijest medicine (59), kliničke psihijatrije (60-62), posttraumatskog stresnog poremećaja (63), psihijatriji srodne teme (64-67), psihoaktivne tvari (68-74), psihoonkologije (75-78), psihologije (79-87), kineziologije (88-91).

\section{SUPLEMENTI PSIHIJATRIJE DANUBINE}

Zahvaljujući kontinuiranom trudu, znanju i iskustvu, pišući i objavljujući kvalitetne radove u Zdravstvenom glasniku naš kvalitetan radje prepoznat $\mathrm{i}$ dobili smo brojne pohvale od uglednih sveučilišnih profesora iz $\mathrm{BiH}$ i regije. Pohvale smo, u nekoliko navrata, dobili i od našeg rektora prof. dr. sc. Zorana Tomića. Ugledni prof. dr. sc. Miro Jakovljević koji već četvrto desetljeće uređujejedan od znanstveno najjačih časopisa u ovom dijelu Europe pod imenom Psychiatria Danubina dao nam je ponudu i mogćnost da uredimo i objavimo svoje radove u Suplementu tog časopisa. Naši asistenti i profesori su u ovom časopisu prije toga objavili nekoliko radova koji su dobili vrlo pozitivne ocjene (92-95).

$\mathrm{U}$ dva navrata imali smo čast i obvezu urediti Suplement Psychiatrie Danubine. U suplementu od 2017. i 2020. godine naši profesori, asistenti i studenti objavili su 25 radova koji su do sada višestruko citirani. Radovi objavljeni u oba suplementa su brzo uvršteni u elektroničku bazu Current Contents. Sve obavljene radove napisali su naši nastavnici i asi- stenti s FZS-a. U broju od 2017. g. objavili smo deset radova. Uglavnom su to bile psihijatrijske teme (96, 97), ali i razne druge komorbidne teme s psihijatrijom (98-105). U Suplementu od 2020. g., koji smo objavili povodom 20 godina našeg fakulteta, objavili smo 15 radova čije su neke teme također bile usko psihijatrijske $(106,107)$, ali i druge koje su povezane s psihijatrijom ili psihologijom (108-115) te aktualne stručno znanstvene teme (116-118). U tom poslu, pišući te radove smo se maksimalno trudili postići što višu razinu i predstaviti sebe, naš Fakultet zdravstvenih studija i naše Sveučilište u Mostaru u što boljem svjetlu. Vrijeme će pokazati što smo uradili, a osobno vjerujemo da smo uspjeli u toj nakani i da smo u području znanosti napravili dobro djelo.

\section{PLANOVI ZA BUDUĆNOST}

Naš plan i naša želja za budućnost je postupno povećavati kvalitetui dizati znanstvenu i stručnu razinu časopisa. To ćemo pokušavati i truditi se preko stručnijeg i aktivnijeg uredničkog odbora koji u više stvari ima ključnu ulogu. Članovi uredničkog odbora su važni i za motiviranje znanstvene zajednice za prijem što većeg broja radova, za objavu u časopisu Zdravstveni glasnik. Kako bi se sljedećih godina povećala prepoznatljivost časopisa na međunarodnoj razini, osim uobičajenog uredničkog odbora važna je uloga i aktivnost međunarodnog, znanstvenog odbora. Danas postoji velika konkurencija znanstvenih i stručnih časopisa na području znanosti koje pokriva časopis Zdravstveni glasnik. Ali mi smo svjesno ušli u tu utakmicu i vjerujemo u naš uspjeh. Do sada smo objavljivali radove iz medicine i zdravstva ali iz svih drugih srodnih disciplina. Objavljivali smo radove osim iz Mostara i Hercegovine iz svih zdravstvenih centara iz $\mathrm{BiH}$, ali i iz sedam drugih zemalja. Ali, mi ne želimo tu stati nego nam je plan širiti se i jačati. Što je veći broj prispjelih radova, veća je mogućnost odabira boljih i kvalitetnijih radova.

Plan nam je povećati i pooštriti kvalitetu recenzija uz želju za uključivanje u elektroničke baze viših razina i već smo na putu i borimo se da postignemo kvalitete i zadovoljimo kriterije za elektroničku bazu Scopus. Planiramo u narednim brojevima povećati broj citata autora i koautora članaka u našem časopi- 
su, kao i u drugim časopisima više indeksacije čime bismo povećali i ukupnu citiranost Zdravstvenog glasnika. Ovaj članak je između ostalog i doprinos uspjeha na tom planu. Naš dugoročni plan je da svojom stručnom i znanstvenom kvalitetom te raznovrsnošću i aktualnošću objavljenih radova privučemo sve veći broj zainteresiranih za objavljivanje kao i sve veći broj čitatelja.

Uređivati znanstveno stručni časopis vrlo je zahtjevna i odgovorna dužnost. Odgovornost se ne odnosi samo na poslove uređivanja časopisa, određivanja pravila autorima pri slanju radova u časopis, na brigu oko pravodobne i temeljne recenzije pristiglih radova, to znači i veliku odgovornost prema čitateljima časopisa. Moraju se prihvatiti njihove potrebe i zanimanja ali treba biti spreman i na kritike. Dakako, od urednika se tražipovećanje kvalitete, planiranje budućnosti časopisa te posebice njegove međunarodne prepoznatljivosti. Svi ti zahtjevi i odgovornosti obvezuju na spremnost za naporan, sustavan i dugotrajan rad jer se jedino tako može ostvariti kontinuirano izlaženje časopisa i podizanje njegove kvalitete.

\section{ZAKLJUČAK}

Fakultet zdravstvenih studija u svojih dvadeset i jednu godinu postojanja zabilježio je veliki uspon i napredak. Od više škole postao je respektabilan fakultet na Sveučilištu u Mostaru, $\mathrm{BiH}$ i regiji. Sa sva tri ciklusa nastave naš fakultet omogućava našim studentima vrhunsko školovanje i velike mogućnosti učenja i napredovanja. Uz dobro organiziran i kvalitetan rad časopis Zdravstveni glasnik doprinosi podizanju sveučilišne razine našeg fakulteta i našeg sveučilišta.

Nastojat ćemo da taj uspon i dalje traje, da držimo visoku razine kvalitete nastave, a da časopisZdravstveni glasnik bude pomoć i potpora na tom putu boljitka. A sve samo u cilju mogućnosti što bolje edukacije naših studenata koji će sutra u praksi pomagati bolesnim osobama, a neki od njih će i biti nastavnici i učiti nove generacije studenata.

\section{LITERATURA:}

1. Vasilj I, Babić D, Tomić V. The Twenty-Year Rise of the Faculty of Health Studies of University of Mostar. Psychiatr Danub 2020; 32: 214-216.

2. Šimić Lj. Fakultet zdravstvenih studija Sveučilišta u Mostaru (šesnaest godina postojanja). Zdravstveni glasnik. 2016; 1: 9-16.

3. Babić D. Psychiatric Saturday in Mostar: the torchbear of Mostar academic Medicine. Medicina Academica Mostariensia. 2014; 2: 5354 .

4. Babić D, Vasilj I, Mimica M. The Faculty of Health Studies at the University of Mostar in the service of health. Psychiatr Danub. 2017; 29 Suppl. 2: 96-100.

5. Mimica M, Babić D, Vasilj I. Važnost i značaj znanosti na fakultetu zdravstvenih studija. Zdravstveni glasnik. 2015; 1: 9-12.

6. Sinanović O, Babić D. Potreba i obveza znanosti na Fakultetu zdravstvenih studija. Zdravstveni glasnik. 2016; 2: 9-13.

7. Tomić Z. Odlučna znanstvena politika, primjena međunarodnih kriterija vrsnoće, izobrazba vrhunskih znanstvenika, beskompromisno poštivanje znanstvenog rada. Zdravstveni glasnik. 2018; 2: 9-14.

8. Miljko M. Ipak znanje vrijedi. Zdravstveni glasnik. 2018; 1: 9-14.

9. Ostojić Lj. Ništa lakše! Zdravstveni glasnik. 2017; 1: 9-10.

10. Pehar V, Vasilj I, Mikulić S. Nadzor nad zaraznim bolestima u Federaciji Bosne i Hercegovine. Zdravstveni glasnik. 2015; 1: 13-17.

11. Vasilj I, Ljevak I. Epidemiološke karakteristike COVID-a 19. Zdravstveni glasnik. 2020; 6 : 9-18.

12. Marković Tomak J, Curić I. Rezultati petogodišnjeg praćenja infektivne mononukleoze u Hercegovačko-neretvanskoj i Dubrovačko-neretvanskoj županiji. Zdravstveni gla- 
snik. 2015; 1: 37-43.

13. Obad A, Curić I, MarkovićTomak J. Rezultati višegodišnjeg praćenja akutnih crijevnih zaraznih bolesti u Hercegovačko-neretvanskoj i Dubrovačkoj županiji. Zdravstveni glasnik. 2015; 2: 73-79.

14. Mešić A, Curić I, Briševac M. Rezultati višegodišnjeg praćenja salmoneloznih infekcija u Federaciji Bosne i Hercegovine. Zdravstveni glasnik. 2016; 1: 36-44.

15. Mimica I, Šegvić O, Nikolić J, Vasilj I, Grgić S. Znanje, stav i praksa zdravstvenih djelatnika o cijepljenju zdravstvenih djelatnika protiv influence u Sveučilišnoj kliničkoj bolnici Mostar. Zdravstveni glasnik. 2015; 1: 51-60.

16. Herceg K, Vasilj I. Nuspojave obveznih cjepiva. Zdravstveni glasnik. 2015; 2: 32-37.

17. Perković R, Medić A, Vasilj I. Znanje, stav i praksa zdravstvenih djelatnika o obveznom cijepljenju na području Hercegbosanske županije. Zdravstveni glasnik. 2015; 2: 55-60.

18. Franjić D, Franjić I, Ravlija J. Značaj komunikacije u prevenciji antivakcinalnih aktivnosti. Zdravstveni glasnik. 2018; 2: 15-24.

19. Šantić M, Čović I. Značaj komunikacije zdravstvenih djelatnika u promociji cijepljenja. Zdravstveni glasnik. 2020; 6: 81-89.

20. Čelan S, Pilić Z. Zdravstveni nadzor vodovoda općine Livno. Zdravstveni glasnik. 2015; 2: 50-54.

21. Kovač B. Mjerenje kvalitete života vezane uz zdravlje kao mjerilo uspješnosti zdravstvene skrbi. Zdravstveni glasnik. 2017; 1: 86-93.

22. Jurišić M, Babić D, Škobić H. Ekološka svijest u gospodarenju otpadom na području grada Mostara. Zdravstveni glasnik. 2019; 5: 67-77.

23. Šimić J, Tomić V, Vukojević M. Lokalna znanstvena infrastruktura u kontekstu zaštite od pandemije COVID-19. Zdravstveni glasnik. 2020; 6: 19-24.

24. Kovač B. Teorije sestrinstva i njihove primje- ne u sestrinskoj kliničkoj praksi. Zdravstveni glasnik. 2018; 1: 79-86.

25. Krstanović J, Perković R, Petričević J. Uloga medicinske sestre u zdravstvenoj njezi bolesnika na hemodijalizi. Zdravstveni glasnik. 2018; 2: 44-49.

26. Perić O, Ljubić M, Tirić D, Tomić V. Zdravstvena njega pupčanog bataljka - iskustva u rodilištu Sveučilišne kliničke bolnice Mostar. Zdravstveni glasnik. 2015; 2: 38-43.

27. Vidakušić K, Perić O, Tomić V, Soken N, Kajić-Mikulić M. Značaj potpore partnera pri porođaju u rodilištu Sveučilišne kliničke bolnice Mostar. Zdravstveni glasnik. 2016; 1: 60-64.

28. Perić O, Tomić V, Tirić D, Margeta I. Etičko-pravne spoznaje pacijentica o informiranom pristanku kod operativnih zahvata ginekoloških pacijentica. Zdravstveni glasnik. 2019; 5: 48-56.

29. Marijanović I, Buhovac T. Onkologija jučer, danas, sutra. Zdravstveni glasnik. 2017; 1: 9498.

30. Bačić M, Babić D, Pavlović M. Usporedba kvalitete života i psihičkih simptoma u onkoloških pacijenata liječenih kemoterapijom i zračenjem. Zdravstveni glasnik. 2018; 1: 1522.

31. Đolo M, Šimić J, Vasilj I. Analiza učestalosti i stope obolijevanja od raka prostate u Federaciji Bosne i Hercegovine. Zdravstveni glasnik. 2019; 5: 33-39.

32. Franjić D, Marijanović I. Prevencija i rano otkrivanje karcinoma debelog crijeva u vrijeme pandemije covid-19. Zdravstveni glasnik. 2020; 6: 96-104.

33. Rastović P, Šekerija S, Kordić M, Azinović A, Brekalo Z. Učestalost komorbidnih bolesti u oboljelih od kolorektalnog adenokarcinoma. Zdravstveni glasnik. 2016; 1: 45-53.

34. Palac I, Šumanović-Glamuzina D, Mikulić I, Galić G. Proširenost dojenja i čimbenici 
koji uvjetuju odustajanje od dojenja na području Mostara. Zdravstveni glasnik. 2016; 2: $35-46$.

35. Stojčić O, Marijanović M, Knežević J. Hemolitička bolest novorođenčeta: direktni coombs test. Zdravstveni glasnik. 2016; 2: 83-88.

36. Berberović M, Pravdić D. Dijagnostička vrijednost srednjeg volumena, broja trombocita i trombokrita u akutnoj emboliji pluća. Zdravstveni glasnik. 2017; 1: 19-28.

37. Obradović-Salčin L, Hrkač A, Miljanović Damjanović V. Liječenja kritične lumbalne boli elektroterapijom, manualnom trakcijom i kineziterapijom. Zdravstveni glasnik. 2015; 2: 25-31.

38. Hrkać A, Obradović - Salčin L, Miljanović Damjanović V. Učinkovitost McKenzie koncepta i standardne kineziterapije na smanjenje boli kod kronične vertebralne križobolje. Zdravstveni glasnik. 2016; 1: 85-90.

39. Andrić S, Ostojić Lj. Procjena učinkovitosti ranog kineziterapijskog tretmana u bolesnika s moždanim udarom. Zdravstveni glasnik. 2017; 1: 11-18.

40. Brkić S, Obradović-Salčin L, Miljanović Damjanović V, Sušac M, Alagić I. Učinak fizikalne terapije na funkcionalni oporavak $\mathrm{i}$ kvalitetu života kod bolesnika s ugrađenom endoprotezom koljena. Zdravstveni glasnik. 2017; 1: 52-59.

41. Hrkać A, Perković R, Čuljak J, Bagarić I. Učinkovitost trakcije u liječenju spinalnih radikulopatija. Zdravstveni glasnik. 2018; 1: 40-49.

42. Mijatović D, Hrkać A, Brekalo M. Kompetencije fizioterapeuta u suvremenom zdravstvenom sustavu. Zdravstveni glasnik. 2018; 2: 60-67.

43. Grle I, Grle M. Rehabilitacija pacijenata nakon rekonstrukcije prednje križne sveze. Zdravstveni glasnik. 2019; 5: 78-84.

44. Čuvalo J, Cigić D, Markotić F. Fizioterapij- ski pristup djetetu slegg-calve-perthesovom bolesti - prikaz slučaja. Zdravstveni glasnik. 2019; 5: 85-92.

45. Grbavac V, Čerkez Zovko I. Bilateralne razlike, tipovi tjelesnog držanja u rukometaša i njihova veza s igračkom pozicijom. Zdravstveni glasnik. 2019; 5: 15-25.

46. Tojaga A, Obradović Salčin L, Miljanović Damjanović V. Procjena učinka klasične kineziterapije i bobath koncepta na razinu neovisnosti pacijenata s ishemijskim moždanim udarom. Zdravstveni glasnik. 2020; 6: 51-59.

47. Brkić S, Krstičević B, Ostojić Lj. Učinak schanzovog ovratnika na smanjenje onesposobljenja vratne kralježnice i intenzitet boli u akutnom bolnom vratnom sindromu. Zdravstveni glasnik. 2020; 6: 23-30.

48. Krpan M, Miljko M. Fraktura kuka: usporedba nalaza konvencionalne radiografije i kompjutorizirane tomografije. Zdravstveni glasnik. 2015; 1: 61-65.

49. Đopa A, Miljko M. Ozljede zajedničke tetive mišića ekstenzora podlaktice: Usporedba nalaza ultrazvuka i magnetne rezonance. Zdravstveni glasnik. 2015; 2: 44-49.

50. Franjić D, Mašković J. Usporedba 3d tehnike i digitalne subtrakcijske angiografije $\mathrm{u}$ detekciji intrakranijalnih aneurizmi i njihove lokalizacije. Zdravstveni glasnik. 2018; 1: 23-32.

51. Jurišić S, Planinić D, Sabljo S. Radiologija u stomatologiji. Zdravstveni glasnik. 2019; 5: 86-94.

52. Jurilj M, Jerković A, Šimić J. Stavovi i znanje zdravstvenih djelatnika o primjeni prakse zasnovane na dokazima u radiologiji. Zdravstveni glasnik. 2020; 6: 53-60.

53. Franjić D, Miljko M. Umjetna inteligencija u radiologiji: etički problemi. Zdravstveni glasnik. 2020; 6: 61-69.

54. Bagarić M, Babić D, Pavlović M. Anksioznost i depresivnost pacijenata kojima je ordinirana pretraga magnetnom rezonancom. Zdrav- 
stveni glasnik. 2018; 1: 33-39.

55. Margeta I, Vasilj M, Gačić V, Perić O. Učinak uzorkovanja krvi na koncentraciju hemoglobina u hospitaliziranih bolesnika. Zdravstveni glasnik. 2019; 5: 57-66.

56. Kolakušić M, Tomić M. Koronarografija kao elektivna metoda otkrivanja bolesti koronarnih arterija. Zdravstveni glasnik. 2020; 6: 4250 .

57. Katavić Z, Šimunović M, Perković M, Katavić Z, Babić D. Kvaliteta života paraplegičara. Zdravstveni glasnik. 2016; 2: 57-64.

58. Vukić I, Pravdić D. Važnost pravilne prehrane osoba oboljelih od šećerne bolesti. Zdravstveni glasnik. 2020; 6: 71-80.

59. Mandić K, Tomić P. Medicina bosanskohercegovačkih franjevaca od 13. do početka 20. stoljeća. Zdravstveni glasnik. 2020; 6: 95-103.

60. Pavlović M, Babić D, Rastović P. Učestalost metaboličkog sindroma $\mathrm{u}$ oboljelih od shizofrenije. 2015; 1: 18-24.

61. Adrić I, Babić D. Kvaliteta života kroničnih duševnih bolesnika. Zdravstveni glasnik. 2015; 2: 15-24.

62. Pavlović M, Krešić Ćorić M, Nikolić K, Dodoš N, Grbavac K, Babić R, i sur. Pojavnost suicidalnosti u bolesnika hospitaliziranih na Klinici za psihijatriju SKB Mostar u periodu 2004. -2013. Zdravstveni glasnik. 2016; 1:2635.

63. Babić I, Babić D, Martinac M. Psihički simptomi i kvaliteta života studenata iz obitelji s iskustvom rata. Zdravstveni glasnik. 2016; 2: 27-34.

64. Ledić L, Šušac A, Ledić S, Babić R, Babić D. Depresija u djece i adolescenata. Zdravstveni glasnik. 2019; 5: 75-85.

65. Badrov S, Babić D, Franjić D, Martinac M, Miljko M. Anksioznost pacijenata kod pregleda višeslojnom kompjutoriziranom tomografijom u Županijskoj bolnici Livno. Zdravstveni glasnik. 2020; 6: 13-22.
66. Planinić K, Mandić G, Šimić J. Informacijska anksioznost studenata Fakulteta zdravstvenih studija Sveučilišta u Mostaru. Zdravstveni glasnik. 2020; 6: 31-41.

67. Barbarić R, Vasilj I. Komplementarna medicina u psihijatriji. Zdravstveni glasnik. 2020; 6: 76-87.

68. Jakešević A, Martinac M. Prevalencija zlouporabe marihuane i hašiša među učenicima srednjih škola u Jajcu. Zdravstveni glasnik. 2015; 1: 25-36.

69. Soča M, Babić D. Pojavnost psihoaktivnih tvari u srednjoškolske mladeži. Zdravstveni glasnik. 2015; 1: 44-50.

70. Batori M, Žerovnik A, Barać K, Babić D. Pozitivni učinci kanabisa na zdravlje. Zdravstveni glasnik. 2018; 2: 50-59.

71. Bošnjak M, Mandić K, Babić D. Prevalence of psychoactive substance use among students of Secondary Medical School "the Sisters of Mercy" in Mostar. Zdravstveni glasnik. 2019; 5: 24-32.

72. Ajtlbez L, Babić D. Shoppingholizam - ovisnost modernog doba. Zdravstveni glasnik. 2016; 2: 72-82

73. Janjić M, Barać K, Grbavac K, Grbavac V, Babić R, Martinac M, i sur. Kvaliteta života i psihički simptomi ovisnika o opijatima. Zdravstveni glasnik. 2019; 5: 36-44.

74. Marić J, Babić D. Pojavnost uporabe psihoaktivnih tvari studenata Fakulteta zdravstvenih studija Sveučilišta u Mostaru. Zdravstveni glasnik. 2020; 6: 33-41.

75. Vlašić A. Ličnost žena oboljelih od karcinoma dojke. Zdravstveni glasnik. 2017; 1: 45-51.

76. Perković R, Vlašić A, Hrkać A, Vasilj I. Kvaliteta života žena oboljelih od raka dojke na području livna. Zdravstveni glasnik. 2018; 1: 50-57.

77. Hrkać I, Pavlović M, Haxhibeqiri S, Babić R, Martinac M, Babić D. Usporedba anksioznosti i depresivnosti u onkoloških pacijenata 
liječenih kemoterapijom i zračenjem. Zdravstveni glasnik. 2019; 5: 40-47.

78. Franjić D, Babić D, Marijanović I. Karcinom debelog crijeva i rezilijencija. Zdravstveni glasnik. 2019; 5: 66-74.

79. Tadić T, Bevanda D, Babić D, Vasilj I, Martinac M. Kvaliteta života i samopoštovanje studenata Sveučilišta u Mostaru smještenih u studentski dom Mostar. Zdravstveni glasnik. 2016; 1: 17-25.

80. Železnik D, Kanisek R, Železnik U. Usporedba usamljenosti adolescenata i starijih osoba u ustanovama socijalne skrbi. Zdravstveni glasnik. 2016; 2: 14-26.

81. Šimić D, Babić D. Kvaliteta života studenata Sveučilišta u Mostaru. Zdravstveni glasnik. 2017; 1: 29-35.

82. Ljevak I, Romić M, Vasilj I, Šimić J, Perić O. Izvor stresa u medicinskih sestara - primalja Sveučilišne kliničke bolnice Mostar. Zdravstveni glasnik. 2016; 2: 65-71.

83. Ljubić O, Babić D. Anksioznost studenata Fakulteta zdravstvenih studija u Mostaru prije i nakon ispita. Zdravstveni glasnik. 2017; 1: 36-44.

84. Bekavac D, Dilber S, Babić R. Glazbom protiv stresa. Zdravstveni glasnik. 2018; 1: 98-104.

85. Jurišić M, Vlašić A, Bagarić I. Stres na radnom mjestu kod zdravstvenih djelatnika. Zdravstveni glasnik. 2019; 5: 45-52.

86. Babić D, Babić M, Ćurlin M. Kako se sačuvati od stresa za vrijeme pandemije koronom. Zdravstveni glasnik. 2020; 6: 25-32.

87. Batori M, Curlin M, Babić D. Nasilje putem interneta među adolescentima. Zdravstveni glasnik. 2020; 6: 104-114.

88. Katić S, Kvesić M, Lukanović B, Babić M. Učinak tjelovježbe na kvalitetu života žena srednje životne dobi. Zdravstveni glasnik. 2018; 2: 25-32.

89. Babić M, Čerkez Zovko I, Martinac M, Babić R, Katić S, Lukanović B. Povezanost tjelo- vježbe i duševnog zdravlja studenata. Zdravstveni glasnik. 2018; 2: 33-43.

90. Babić M, Čerkez Zovko I, Tomić V, Perić O. Tjelovježba tijekom i poslije trudnoće. Zdravstveni glasnik. 2019; 5: 53-65.

91. Marić I, Lovrić F, Franjić D. Utjecaj rekreacijskih aktivnosti na mentalno zdravlje. Zdravstveni glasnik. 2020; 6: 105-114.

92. Babić R, Maslov B, Babić D, Vasilj I. The prevalence of metabolic syndrome in patient with posttraumatic stress disorder. Psychiatr Danub. 2013; 5: 45-50.

93. Dilber R, Babić D, Vasilj I, Martinac M, Babić R, Aukst-Margetić B. Religiosity and mental health in nursing students. Psychiatr Danub. 2016; 28: 188-92.

94. Pavlović M, Babić D, Rastović P, Babić R, Vasilj M. Metabolic syndrome, total and differential white blood cell counts in patients with schizophrenia. Psychiatr Danub. 2016; 28: $216-22$.

95. Babić D, Babić R, Vasilj I, Avdibegović E. Stigmatization of mentally ill patients through media. Psychiatr Danub. 2017; 29: 885-889.

96. Mirković-Hajdukov M, Spahić TE, Softić R, Bećirović E, Šimić J. Family atmosphere and relationships as predictors of heroin addiction. Psychiatr Danub. 2017; 29: 129-133.

97. Šimunović $M$, Tokmakčija S, Pavlović $M$, Babić R, Vasilj M, Martinac M, i sur. The impact of religiosity on quality of life and psychological symptoms in chronic mental patients. Psychiatr Danub. 2017; 29: 118-123.

98. Gunarić A, Jurišić K, Šimić D, Zeljko Penavić J, Jozić S, Goluža I. Scabies mimicing child abuse - a case report. Psychiatr Danub. 2017; 29: 145-147.

99. Markotić V, Miljko M, Radančević D, Grle M, Perić I, Arapović AK, i sur. A case report of a long time unrecognized hypochondriac patient wondering through the hospital departments. Psychiatr Danub. 2017; 29: 142-144. 
100. Rastović P, Trninić Z, Galić G, Brekalo Z, Lesko J, Pavlović M. Accuracy of Modified Alvarado Score, Eskelinen Score and Ohmann Score in diagnosing acute appendicitis. Psychiatr Danub. 2017; 29: 134-141.

101. Vasilj M, Klarić M, Vrkić N, Mikulić I, Boras MM, Jelić-Knezović N, i sur. Kappa free light chains in cerebrospinal fluid of patients with identified oligoclonal immunoglobulin G. Psychiatr Danub. 2017; 29: 124-128.

102. Vukojević M, Cvitković T, Splavski B, Ostojić Z, Šumanović-Glamuzina D, Šimić J. Prevalence of intellectual disabilities and epilepsy in different forms of spastic cerebral palsy in adults. Psychiatr Danub. 2017; 29: 111-117.

103. Šimić D, Penavić JZ, Babić D, Gunarić A. Psychological status and quality of life in acne patients treated with oral osotretinoin. Psychiatr Danub. 2017; 29: 104-110.

104. Ravlija J, Vasilj I, Babic D, Marijanovic I. Public health achievements and challenges: Symposium of the University of Mostar Faculty of Health Studies. Psychiatr Danub. 2017; 29: 101-103.

105. Babić D, Vasilj I, Mimica M. The Faculty of Health Studies at the University of Mostar in the service of health. Psychiatr Danub. 2017; 29: 96-100.

106. Ajtlbez L, Babić D, Franjić D, Barać K, Martinac M, Haxhibeqiri SS. Psychic symptoms and self-esteem in dancers. Psychiatr Danub. 2020; 32: 244-253.

107. Krešić Ćorić M, Kaštelan A. Bullying through the Internet - Cyberbullying. Psychiatr Danub. 2020; 32: 269-272.

108. Babić R, Babić M, Rastović P, Curlin M, Šimić J, Mandić K, i sur. Resilience in health and illness. Psychiatr Danub. 2020; 32: 226232.

109. Markotić V, Pokrajčić V, Babić M, Radančević $\mathrm{D}$, Grle M, Miljko M, i sur. The positive effects of running on mental health. Psychiatr Danub. 2020; 32: 233-235.

110. Lukanović B, Babić M, Katić S, Čerkez Zovko I, Martinac M, Pavlović M, i sur. Mental health and self-esteem of active athletes. Psychiatr Danub. 2020; 32: 236-243.

111. Kvesić A, Babić D, Franjić D, Marijanović I, Babić R, Martinac M. Correlation of religiousness with the quality of life and psychological symptoms in oncology patients. Psychiatr Danub. 2020; 32: 254-261.

112. Ljevak I, Vasilj I, Ćurlin M, Šaravanja N, Meštrović T, Šimić J, i sur. The impact of shift work on psychosocial functioning and quality of life among hospital-employed nurses: a cross-sectional comparative study. Psychiatr Danub. 2020; 32: 262-268.

113. Gunarić A, Tomić I, Babić R, Gunarić F, Prlić M, Mandić M, i sur. Sensitive skin in the population of Herzegovina-Neretva county: prevalence and clinical data. Psychiatr Danub. 2020; 32: 290-297.

114. Brkić J, Gunarić A, Tomić I, Musa Leko I, Gunarić F, Mandić M, i sur. Report of two psychodermatological cases: neurotic excoriation and dermatitis artefacta. Psychiatr Danub. 2020; 32: 298-301.

115. Šimunović Glamuzina D, Jerković Raguž M, Brzica J. Child protection - humanistic or egoistic orientation. Psychiatr Danub. 2020; 32: 302-04.

116. Vasilj I, Babić D, Tomić V. The twenty-year rise of the Faculty of Health Studies of University of Mostar. Psychiatr Danub. 2020; 32: 214-16.

117. Babić D, Martinac M. The twenty-year rise of psychiatric science in Mostar. Psychiatr Danub. 2020; 32: 217-20.

118.Vasilj I, Herceg K, Čović I, Šantić M, Curlin M, Ljevak I, i sur. Determinants of the COVID-19 pandemic in the West Herzegovina Canton. Psychiatr Danub. 2020; 32: 221-25. 